MR. DE MORGAN, THE GENTLE PURIST.

To the Elitor of The LAxceT.

SIR,-The part which Mr. de Morgan has recently been playing is in snch direct contrast to his previous conduct, that it may bo worth while to induce the profession to look back to events which occurred some years ago. I propose to show that kindness of heart and a love of justice, the motives assigned for his knight-errantry in the cause of $\mathrm{Mr}$. Gay, may not have existed.

Five or six years ago this Mr. de Morgan was assistant-surgeon to the Middlesex Hospital. Mr. Tuson, the founder of the medical school, was then surgeon to the hospital. For many years Mr. Tuson had been attached to the surgical staff, and it was admitted, even by his enemies, that he had always performed his professional duties with great zeal and ability. He was a poor man, with a large and expensive family. His means being scanty, his domestic demands many and imperative, some irregularities oocurred with the fees he received, and that ought to have been immediatly divided amongst the other teachers. In consequence of this misconduct, a private investigation took place, and he was punished by being compelled to give up his office as Lecturer on Anatomy. The penalty for his offence was thus inflicted; Justice was satisfied. Mr. Tuson still, howerer, remained a bar to Mr. de Morgan's ambition, for he continued to be surgeon, while the latter was only the assistant. And now commenced a heartless and unchristian persecution. De Morgan's coteries began quietly to whisper that he who had been deemed unfit for the school must be unfit for the lospital. After a good deal of trickery, the governors were persuaded to put Mr. Tuson upon his trial a second time for the very same offence, be it observed, for which he had already been punished. It may appear incredible, but it is nevertheless true, that De Morgan, if not the avowed prosecutor of his senior officer, took the most active part in creating the desired vacancy. After a stormy war of words, of many days' duration, Mr. Tuson was turned out, and De Morgan walked into the racant office. Since that affair he has been a marked man, and he may rest assured that he "can only escape from public censure when he escapes from observation." Does he find, from the extent of his practice as a consulting-surgeon, that he is supported by his professional brethren? His treatment of KDW A R.D Tuson, and his efforts to eject his superior officer, and obtain his place, will not, and cannot, be forgotten.

I remain, Sir, your obedient servant,

March, 1854.

M.D.

\section{THE ANALYTICAL SANITARY COMMISSION.}

To the Editor of THE LAxcer.

SIR,--In the course of my duty, inspecting arrivals, I have been pleased to notice many indications of the effects of your critical remarks on coloured and dyed tea, now that New Crop Greens are in course of arrival many pale, natural kinds being observable. Four or five classes have particularly arrested my attention, being purely unsophisticated both in manipulation and colour, the latter the bue of an ordinary green-glass bottle when broken thin. On further examination, I find that the inscription on the mat covering the rests is "Uncoloured Tea;" descriptive enough, perhaps, seeing that we have no better English word to designate the desideratum. Should you wish it, I would get samples of these from the bonded warehouses, or accompany any agent of yours to see them there.

Mark-lane, March, 185.4

I am your obedient servant,

$$
\text { W. J. BLALID. }
$$

\section{THE MEDICAL REGISTRATION BILL. To the Eclitor of Trre LANCET.}

SIR,-My attention has been called to a paragraph amongst the Notices to Correspondents, in THE LANCET for March Il, which states-

"We have just been informed by a correspondent that the Medical Practitioners' Registration Bill, introduced into Parliament by Mr. Brady, has been withdrawn at the request of the Govermment," \&c.

As honorary secretary to the committee of medical practitioners who are promoting this measure, I beg to inform you that such statement is not correct; on the contrary, we have reason to believe that the Government looks most favourably on Mr. Brady's Bill; whilst the assurances of cordial assent, and the petitions in farour of this measure, which $\mathrm{Mr}$. Brady daily receives, from all parts of the country, but the more confirms him in the opinion that the suppression of illegal practice is the chief want of existing medical practitioners, and the key-stone of future medical reform.

I have the honour to be, Sir,

Your faithful servant,

Denbigh-street, Belgravia, March, 1854.

G. Burton Payne:

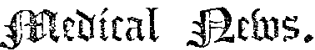

Royat Coltege of SURgeors.-The following gentlemen, having undergone the necessary examinations for the diploma, were admitted members of the College at a meeting of the Court of Examiners on the 10th inst.:-

Davies, Henry Nauxton, C'ymmer Works, Pontypridd, Glamorganshire.

Griffith, John, Army.

Harris, William, Waterford.

MAKIN, WILLIAM HExRT, Lancaster.

Mavmder, Charlies Frederictr, Exeter.

Robins, Bendamin Sivage, Dunsley Hall, near Stourbridge. SHoRT', Joms, Madras.

Thomas, James Prichard, Aberdare, Glamorganshire.

Webr, Jomr Craske, Shaftesbury-crescent, Pimlico.

Wright, GEoRge, Manchester.

House of Conmons. - The following petitions were presented to the House on Monday night:-By Mr. Lucas, from John Kay, M.R.C.S., old-street, St. Luke's; from William Dundas Key, M.R.C.S.; Matthew Coleman, M.R.C.S.; J. G. Benrebell, M.R. C.S.; H. Dermott, M.R.C.S. James Yarsbury, M.R.C.S.; Mr. E. Humble, M.D.; J. S. Iurden, M.R.C.S.; E. Doubleday, M.R.C.S.; by Mr.'Brady from Joseph Tuke, M.R.C.S., and Thomas Cathell, M.D.; all in favour of the Medical Registration Bill; in favour of Medical Registration Bill from G. B. Payne, M.D., H. A. Aldred, M.D., Charles Brady, M.D.; by Mr. J. Ball, from James Glepham, T. G. Thibay, M.R.C.S., H. B. Evens, M.R.C.S. Mr. Masters Smith; by Mr. Kirk, from the medical practi tioners in and near Newry, praying the House to take into its favourable consideration the grierances under which the naval medical officers now labour.

Letrisoman Lectures.-Dr. Theophilus Thompson delivered his first lecture on March 15, on "The Epithelial Origin of Pulmonary Consumption, and the Possibility of Detecting by Microscopical Examination of the Expectoration, the Character and Activity of the Disease." On the 22nd, at half-past eight, the second lecture will be delivered: subject"Pulmonary Consumption as a Constitutional Disease."

Apporntunen of Poblic Avalyzers.-We understand that Mr. Postgate, the lecturer on anatomy at Sydenham College, who had previously directed public attention to the subject, has, in a correspondence with $\bar{I}_{\text {r. Scholefield, suggested }}$ the appointment by Government of properly-qualified officers at the various ports, for the purpose of preventing the importation of adulterated articles of food, drugs, \&c., and also the appointment, by town councils and county magistrates, of public analyzers for towns and districts, to examine the same descriptions of articles which there may be reason to suspect have undergone the process of deterioration. It is proposed to confer upon magistrates a summary jurisdiction in such cases, by giving them power to inflict penalties upon parties who are proved to be guilty of selling any of the sirecified commodities in an impure state. Mr. Scholefield, we are informed, approves of the object sought to be attained, and has expressed his readiness to do anything in his power to secure for it legislative sanction. The subject is to be fully discussed at a couference which will be shortly held in this town. for the purpose of considering the propriety of brincing it before Parliament. Birminglam A diertiser of $F_{c} b .23,1851$.

Roral Colifge of Persicraxs, Edinburgh.-Tohn Henry Walker, Esq., M.D., of Tonbridge, has, after the usual examination, been unanimously elected a Fellow of the Royal College of Physicians, Elinburgh.

Medical Stomekeepers it Hascar.-Dr. Leonard, serring in Melville Hospital, Chatham, has been named as successor to Dr. M'Kechnie, lately promoted to the rank of IIedical Inspector of Hospitals. The name of Dr. Mansell, of the Excellent, has also been mentioned, and both are eligible officers. 